\title{
Review \\ Tellurium: A Rare Element with Influence on Prokaryotic and Eukaryotic Biological Systems
}

\author{
Silvia Vávrová ${ }^{1}$, Eva Struhárňanská ${ }^{1}$, Ján Turňa ${ }^{1,2}$ and Stanislav Stuchlík ${ }^{1,2, *(1)}$ \\ 1 Department of Molecular Biology, Faculty of Natural Sciences, Comenius University, Ilkovičova 6, \\ 84215 Bratislava, Slovakia; siliva.vavrova@uniba.sk (S.V.); struharnans1@uniba.sk (E.S.); \\ jan.turna@uniba.sk (J.T.) \\ 2 Science Park, Comenius University, Ilkovičova 8, 84104 Bratislava, Slovakia \\ * Correspondence: stanislav.stuchlik@uniba.sk
}

check for updates

Citation: Vávrová, S.; Struhárňanská, E.; Turňa, J.; Stuchlík, S. Tellurium: A Rare Element with Influence on Prokaryotic and Eukaryotic Biological Systems. Int. J. Mol. Sci. 2021, 22, 5924. https://doi.org/10.3390/ ijms22115924

Academic Editors: Martin Kolisek, Rhian Touyz, Gerhard Sponder and Andrea Fleig

Received: 1 May 2021

Accepted: 28 May 2021

Published: 31 May 2021

Publisher's Note: MDPI stays neutral with regard to jurisdictional claims in published maps and institutional affiliations.

Copyright: (c) 2021 by the authors. Licensee MDPI, Basel, Switzerland. This article is an open access article distributed under the terms and conditions of the Creative Commons Attribution (CC BY) license (https:/ / creativecommons.org/licenses/by/ $4.0 /)$.

\begin{abstract}
Metalloid tellurium is characterized as a chemical element belonging to the chalcogen group without known biological function. However, its compounds, especially the oxyanions, exert numerous negative effects on both prokaryotic and eukaryotic organisms. Recent evidence suggests that increasing environmental pollution with tellurium has a causal link to autoimmune, neurodegenerative and oncological diseases. In this review, we provide an overview about the current knowledge on the mechanisms of tellurium compounds' toxicity in bacteria and humans and we summarise the various ways organisms cope and detoxify these compounds. Over the last decades, several gene clusters conferring resistance to tellurium compounds have been identified in a variety of bacterial species and strains. These genetic determinants exhibit great genetic and functional diversity. Besides the existence of specific resistance mechanisms, tellurium and its toxic compounds interact with molecular systems, mediating general detoxification and mitigation of oxidative stress. We also discuss the similarity of tellurium and selenium biochemistry and the impact of their compounds on humans.
\end{abstract}

Keywords: tellurium; tellurite resistance; human diseases; oxidative stress

\section{Tellurium and Its Occurrence}

Tellurium (Te) is a member of the chalcogen group, which includes oxygen, sulphur, selenium (Se) and polonium [1]. The first three members of the chalcogen group have crucial functions in biochemistry, biology and medicine, whereas Te is a strange element with no apparent role in biological systems. Moreover, it belongs to the group of very few elements in the Periodic Table that have been almost completely ignored. Elemental tellurium $\mathrm{Te}^{0}$ has the chemical properties of a nonmetal or metalloid and the physical properties of a metal. Its chemistry is similar to that of Se in many ways [2]. There are many not yet fully understood mechanisms of Te compounds in organisms but Se, with many similarities in properties, can provide a considerable example.

Te is a rare element of the Earth's crust, with a low global and heterogeneous distribution and natural abundance of only about $10^{-2}$ to $10^{-8} \mathrm{ppm}[1,3]$. Information on environmental concentrations of Te is scarce and often misleading due to inadequate analytical methods. Recent known values in surface water indicate concentrations of a few to low tens of $\mathrm{ng} / \mathrm{kg}[4,5]$. There are unknown data about elemental Te concentrations in crust [5], and values for soil concentrations differ with a broad range from $0.008 \mathrm{mg} / \mathrm{kg}$ to $0.03 \mathrm{mg} / \mathrm{kg}$ [5], and in some localities that are naturally anthropologically enriched with Te, compounds can reach from $0.166 \mathrm{mg} / \mathrm{kg}$ [6] even up to $0.5 \mathrm{mg} / \mathrm{kg}$ [7]. Because of human industrial activities, Te-containing compounds can arise as environmental pollutants [8,9]. Te compounds are mostly found as tellurides of copper, gold and silver ores [10]. In areas adjacent to gold mines, the concentration of Te reaches extreme values of up to $14.8 \mathrm{ppm}$ [11]. Te is also a by-product of the electrolytic refining of copper. During this 
process, the anode muds produced as a by-product are commercially used as they contain up to $8 \%$ Te. Te forms alloys with other metals, mainly copper, gold and silver [12], and can be incorporated into stainless steel, lead and bronze to improve their machinability and to make them more resistant to corrosion. Te has been used to create photovoltaic modules [13] and high-efficiency thermoelectric generators [14], in the vulcanization of rubber (in which it increases resistance to heat, abrasion and aging) and in metal-oxidizing solutions to blacken or tarnish metals (in jewellery manufacturing) [15]. Tellurite can form part of the pigments for the colouring of glass and ceramics [16], which is present in rechargeable batteries [17] and is also a component of solar panels and rewritable CDs and DVDs. Its occurrence in places with high anthropogenic industrial activities [18] causes environmental problems that not only destroy the microbial ecology of soil but also pose a serious risk to human health, since Te compounds are highly toxic with a teratogenic effect in rats [19]. The elementary $\mathrm{Te}^{0}$ has been classified as non-toxic for living forms [20] in comparison with soluble Te oxyanions [21].

Te compounds can be divided into three groups: (a) inorganic tellurides; (b) Tecontaining complex-like structures; and (c) organotellurides [2]. Inorganic Te compounds occur be in various oxidation states ranging from -II to +VI, namely - $\mathrm{II}\left(\mathrm{H}_{2} \mathrm{Te}\right.$, hydrogen telluride), 0 ( $\mathrm{Te}^{0}$ elemental tellurium), $+\mathrm{II}\left(\mathrm{TeO}\right.$, tellurium monoxide), $+\mathrm{IV}\left(\mathrm{TeO}_{3}{ }^{2-}\right.$, tellurite) and $+\mathrm{VI}\left(\mathrm{TeO}_{4}{ }^{2-}\right.$ tellurate). These oxides form tellurous acid $\left(\mathrm{H}_{2} \mathrm{TeO}_{3}\right)$ and telluric acid $\left(\mathrm{H}_{2} \mathrm{TeO}_{4}\right)$ and their salts are known as tellurites $\mathrm{TeO}_{3}{ }^{2-}$ and tellurates $\mathrm{TeO}_{4}{ }^{2-}$. The anion $\mathrm{TeO}_{2}{ }^{2-}$ in the oxidation state of $+\mathrm{II}$ also exist $[1,22]$. Te-containing complex-like structures have been studied extensively in a biological context. They contain a central Te atom, which is bound to a range of ligands. Ligand changes are responsible for the majority of the biological activities of various cysteine proteases [23]. For instance, an active site change at the Te atom results in the inactivation of cysteine protease. This process has a wide range of implications in connection with tumour invasion. Organic Te agents have GPx-like activity, as shown by tests in vitro in which organotellurides have been used as mimics of the antioxidant GPx (glutathione peroxidase), because of their resemblance to the human Se-containing enzyme GPx [24,25]. Some organotellurides have a biochemical activity that mimics vitamin $\mathrm{E}$ [26].

\section{Effects of Tellurium and Its Compounds on Selected Prokaryotic Systems}

\subsection{Mechanism of Toxicity}

Tellurites are highly toxic, even at micromolar levels $(1 \mu \mathrm{g} / \mathrm{mL})$ [27-29]; however, there are no recorded thresholds according to the OSHA and NIOSH databases. The toxicity of potassium tellurite $\left(\mathrm{K}_{2} \mathrm{TeO}_{3}\right)$ was recorded for the first time by Sir Alexander Fleming in 1932 [30]. These compounds were used for the treatment of some medical conditions such as syphilis, tuberculosis, cystitis, dermatitis, eye infections and leprosy. Therefore, Te-containing soluble salts were historically used as antimicrobial and therapeutical agents before the era of antibiotics [1].

Te probably exploits the metabolic machinery of Se, and tellurodiglutathione (GSTeSG), which is an analogue of selenodiglutathione (GSSeSG), is produced during $\mathrm{H}_{2} \mathrm{Te}$ formation. The toxicity mechanism of thiol-binding metal(loid)s is based on the interaction and subsequent inhibition of essential thiol groups of enzymes and proteins [31]. The similar physical and electrochemical features of Te to Se and sulphur lead to its substitution of them in proteins [32]. The erroneous incorporation of the resulting tellurocysteine and/or telluromethionine into protein structure leads to changes in protein activity or protein inactivity.

Upon the entry of $\mathrm{TeO}_{3}{ }^{2-}$ into a cell, the transmembrane proton gradient is disrupted in E. coli, irrespective of the level of resistance. This effect is accompanied by the inhibition of ATP synthesis, resulting in the depletion of intracellular ATP stores during aerobic growth [33]. The same detrimental effect of Te compounds has been found in protein synthesis with regard to proteins containing amino acids with reduced thiol groups [34] of both low-level and high-level resistant microbes. Two high-resistant bacteria, namely 
Erythromonas ursincola strain KR99 and Erythromicrobium ramosum E5, are distinct from other microbes, both showing an increase in protein and ATP synthesis in the presence of Te compounds [35]. The mechanism of this increase is uncertain, but it was implied [35-38] that reduction of such oxyanions could help with retaining optimal redox balance.

The reduction of Te compounds in modified cell culture media is accompanied by black colony formation. This chromogenic-based selective cultivation has been used for the diagnosis of the presence of antibiotic-resistant pathogenic bacteria for decades and, despite the emergence of genomic approaches, remains widely used [39-41].

\subsection{Mechanism of Tellurite Resistance}

Three main types of resistance exist: intrinsic, acquired and adaptive.

Intrinsic resistance comprises the inherent properties of a microorganism that limit the action of antimicrobials. The mechanisms of bacterial resistance to toxicants, in general, are extraordinarily diverse. They can be specific, whereby the main role of the cell is to resist the action of a toxic compound, or nonspecific, in which the resistance is based on a component that is involved in other cellular functions but that also exerts a protective effect against the toxicant. The nonspecific mechanisms are carried out at low levels of resistance/reduction [42] and can be enzymatic or non-enzymatic. Resistance can be achieved by mutations that affect the intracellular target for a given antimicrobial drug. Even if the toxicant enters the intracellular milieu and target affinity does not change, bacteria can enhance their resistance by actively expelling the toxicant from their cells by efflux. Another mechanism is based on the reduced entry of the toxicant into the bacterial cell resulting from modifications to the cell surface that restrict interactions with the toxicant or from a reduction in the number of entry channels, such as porins. In the case of no permeability changes, the generally reduced uptake of toxicant through the semipermeable outer membrane acts in synergy with other resistance mechanisms such as enzymatic degradation and efflux [43], for instance, the possession of a semipermeable outer membrane with low permeability, as is the case for the Gram-negative pathogens Pseudomonas aeruginosa and Acinetobacter baumannii, or the constitutive efflux pumps observed in many bacteria.

Acquired resistance occurs when an originally sensitive microbe becomes resistant by incorporating new genetic material (e.g., plasmids, transposons, integrons and naked DNA), by lateral gene transfer, or as a result of mutation. These mutational events may lead to a large increase in the minimal inhibitory concentration [43-45].

Adaptive resistance involves a temporary increase in the ability of a bacterium to survive in the presence of a toxicant by alterations in gene and/or protein expression as a result of exposure to an environmental trigger, e.g., stress, nutrient conditions, growth state and sub-inhibitory levels of the toxicant or antibiotics themselves.

Intrinsic and acquired resistance mechanisms are stable and can be transmitted vertically to subsequent generations. Adaptive resistance has a transient character and usually reverts upon the removal of the inducing condition [43].

Several microorganisms that demonstrate tolerance/resistance to Te compounds have been isolated from various environments [46]. They are able to cope with the toxic environment of $\mathrm{TeO}_{3}{ }^{2-}$ in diverse ways. The first group of organisms horizontally obtained genetic equipment harboured in mobile genetic elements, the most commonly being plasmids, or integrated such genes (e.g., ter genes in E. coli) into their chromosomes and organized them into genomic islands consisting of gene clusters or operons with various gene compositions [47]. Similar gene compositions within a genomic island indicate a lateral transfer from a common ancestor, anciently predestined for survival in the metal-rich environment [42,48]. The second group of organisms evolved other mechanisms enabling cellular enzymes to be used for the reduction of the noxious effects of toxicants. In the first-mentioned group, gene clusters enable resistance against toxicants, whereas the latter triggers the ability to tolerate/adapt to life in a toxic environment. 


\subsubsection{Resistance via the Modulation of Tellurite Efflux}

Tomas and Kay [49] suggested one mechanism of $\mathrm{TeO}_{3}{ }^{2-}$ resistance. They demonstrated that $\mathrm{TeO}_{3}{ }^{2-}$ is transported via the phosphate transport pathway in E. coli $[50,51]$ (Figure 1). The mechanism of such a type of resistance is based on either a chromosomal mutation or on the acquisition of a $\mathrm{TeO}_{3}{ }^{2-}$ resistance plasmid that leads to the inability to transport $\mathrm{TeO}_{3}{ }^{2-}$, the acquisition of an efflux mechanism or the detoxification of the inhibitor [51]. The direct efflux mechanism evolved to prevent the intracellular accumulation of toxic compounds and involves energy-dependent systems that pump such molecules out of the cell in a process that does not alter or degrade the toxicants [43]. However, the direct efflux of $\mathrm{TeO}_{3}{ }^{2-}$ does not constitute a specific resistance mechanism. A decreased influx and increased efflux of $\mathrm{TeO}_{3}{ }^{2-}$ is not responsible for the $\mathrm{TeO}_{3}{ }^{2-}$ resistance of E. coli [52]. Subsequent observations by Borghese et al. [53] revealed that a decreased uptake by an acetate transport system, based on tellurite-acetate competition, is responsible for $\mathrm{TeO}_{3}{ }^{2-}$ uptake and resistance in Rhodobacter capsulatus [54].

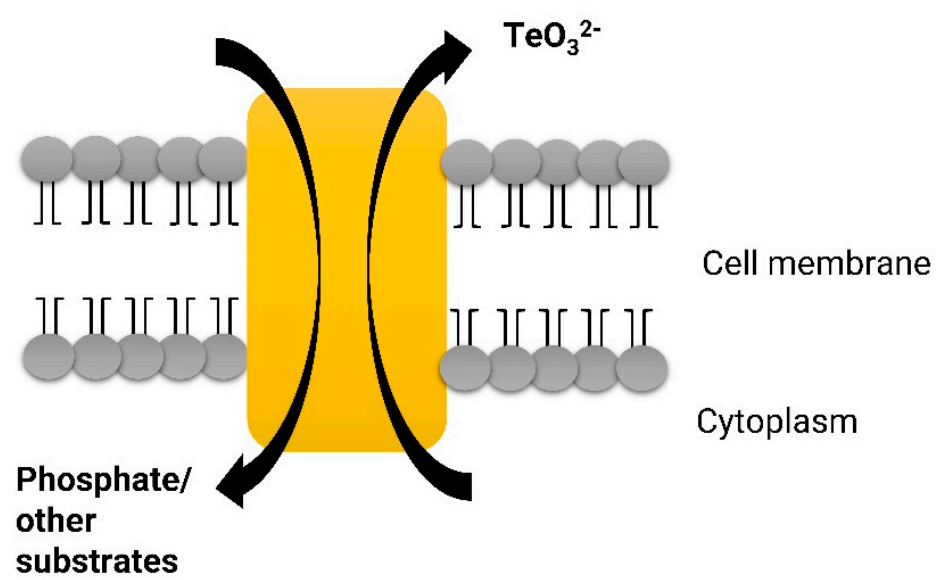

Figure 1. Schematic pathway of efflux of $\mathrm{TeO}_{3}{ }^{2-}$.

\subsubsection{Resistance via Reduction of Tellurite}

One of the mechanisms of $\mathrm{TeO}_{3}{ }^{2-}$ toxicity is based on its high oxidizing ability. The selection of resistance to $\mathrm{TeO}_{3}{ }^{2-}$ and of the ability of some bacteria to reduce $\mathrm{TeO}_{3}{ }^{2-}$ to less toxic elemental Te has been carried out for decades in specific media containing $\mathrm{TeO}_{3}{ }^{2-}$ in various concentrations. As mentioned above, the reduction of $\mathrm{Te} / \mathrm{Se}$ compounds in such modified cell media is accompanied by black/red colony formation, respectively. Despite the emergence of genomic approaches, this chromogenic-based selection continues to be extensively used [39,40].

Several key cellular enzymes are reported to be involved in the defence against ROS generated during $\mathrm{TeO}_{3}{ }^{2-}$ reduction [55]. The first reports describing bacterial colonies with a black phenotype were published by Klett [56] and Scheurlen [57]. These authors described the production of black or grey insoluble $\mathrm{Te}^{0}$ in microorganisms treated with $\mathrm{TeO}_{3}{ }^{2-}$. This phenomenon is caused by the reduction of $\mathrm{TeO}_{3}{ }^{2-}$ or $\mathrm{Te}^{4+}$ to the less toxic $\mathrm{Te}^{0}$. Regardless of the concentration of $\mathrm{TeO}_{3}{ }^{2-}$, this results in the generation of black or grey deposits of metallic $\mathrm{Te}^{0}$ inside the cell [20]. The same observation was made by Yurkov et al. [58] who also pointed out that $\mathrm{TeO}_{3}{ }^{2-}$ reduction accompanied by black/grey colony formation and metallic Te crystal formation in obligate aerobic photosynthetic bacteria was not essential for the maintenance of high $\mathrm{TeO}_{3}{ }^{2-}$ resistance. White-colony formation without $\mathrm{TeO}_{3}{ }^{2-}$ reduction has also been described in highly tellurite-resistant E. coli strains [59]. Many non-tellurite resistant microorganisms are able to reduce $\mathrm{TeO}_{3}{ }^{2-}$ at low concentrations, one such example being E. coli $\mathrm{K} 12$ [27,60]. A major mechanism of resistance involves the inactivation of the toxicant by enzymes. The reduction of $\mathrm{TeO}_{3}{ }^{2-}$ to $\mathrm{Te}^{0}$, in this case, can be also carried out by the activity of the plasma membrane flavin-dependent reductase $[38,61]$. Several types of non-specific/housekeeping enzymes can be involved in 
the detoxification process of $\mathrm{TeO}_{3}{ }^{2-}$ reduction, e.g., the thiol:disulphide oxidoreductase of Rhodobacter capsulatus [62] and GutS of E. coli [63]. Catalases are also involved in the detoxification of $\mathrm{TeO}_{3}{ }^{2-}$ by affecting its reduction state in Staphylococcus epidermidis [64]. In addition, periplasmic and membrane-associated nitrate reductases have been described in E. coli and Rhodobacter sphaeroides; although having a diverse primary function, all of these non-specific enzymes are known to confer low-level $\mathrm{TeO}_{3}{ }^{2-}$ resistance $[60,65]$. Details of only three specific $\mathrm{TeO}_{3}{ }^{2-}$ reductases have been published to date: the cytoplasm-localized reductase of Bacillus spp. [66,67], the periplasmic $\mathrm{TeO}_{3}{ }^{2-}$ reductase of the Gram-negative facultative anaerobe Shewanella fridigimarina [68] and the membrane-associated reductase of an aerobic anoxygenic phototroph Erythromonas ursincola [69].

\subsubsection{Resistance via Formation of Tellurium Organic and Volatile Compounds}

Bonificio and Clarke [70] have proposed a steady-state system of Te compounds in Pseudoalteromonas spp. strain EPR3. They have demonstrated that, even though many Te compounds are considered insoluble, they can nonetheless be transformed and suggest that a steady-state soluble Te concentration exists during Te transformation. This system is based on solid Te sources (tellurium dioxide, autoclave slime, cadmium telluride, bismuth telluride) being able to dissolve to yield soluble $\mathrm{TeO}_{3}{ }^{2-}$. The $\mathrm{TeO}_{3}{ }^{2-}$ enters the cell and the bacterium transforms it to either metallic elemental Te or a gaseous Te species (dimethyl telluride $\mathrm{C}_{2} \mathrm{H}_{6} \mathrm{Te}$ ) $[20,71,72]$. The system stays in a steady-state in which the undissolved Te source, the metallic $\mathrm{Te}, \mathrm{TeO}_{3}{ }^{2-}$ and volatile Te compounds are present. Solid elemental Te dissolves to $\mathrm{TeO}_{3}{ }^{2-}$, which can be converted to a gaseous Te species and subsequently excreted to the environment by volatilization [73]. Volatile Te species might also be transformed back to $\mathrm{TeO}_{3}{ }^{2-}$ [70]. The production of organic Te compounds, such as dimethyltelluride, is considered to be one of the detoxification mechanisms of bacteria [3,72].

\subsubsection{Ter-Gene-Mediated Resistance}

Jobling and Ritchie [74] described, for the first time, $\mathrm{a} \mathrm{TeO}_{3}{ }^{2-}$ resistance (ter) determinant of the plasmid pMER610 of Alcaligenes sp. Subsequently, plasmid pR478 harbouring additional ter genes was found in the opportunistic pathogen Serratia marcescens [75]. The nosocomial pathogen Klebsiella pneumoniae CG43 possesses the ter-gene-containing plasmid pLVPK [76]. Several different Escherichia coli pathogens also possess ter gene clusters. The uropathogenic E. coli KL53 strain $[59,77,78]$ and the widely known foodborne pathogen E. coli $\mathrm{O} 157: \mathrm{H7}[79,80]$ have ter gene clusters incorporated into large plasmids. Ter genes have also been identified as part of the chromosomal genomic island of E. coli O157:H7, an interesting observation in the context of horizontally transferred pathogenicity islands as tools of microbial evolution $[47,81]$. The other described $\mathrm{TeO}_{3}{ }^{2-}$ resistant strains are Vibrio cholerae [49], Corynebacterium diphtheriae, Staphylococcus aureus, Shigella spp. [82], the $\mathrm{TeO}_{3}{ }^{2-}$ - and $\mathrm{SeO}_{3}{ }^{2-}$-resistant bacteria of hydrothermal vents Pseudoalteromonas sp. [83], Bacillus subtilis and Yersinia pestis [84]. Muñoz-Villagrán et al. [85] have described a new $\mathrm{TeO}_{3}{ }^{2-}$-resistant Antarctic strain, namely Psychrobacter glacincola, which has great biotechnological potential for low-temperature applications and bioremediation. The most recent strain showing great promise in the bioremediation of toxic Te(IV) contamination is Shinella sp. [86]. Furthermore, $\mathrm{a} \mathrm{TeO}_{3}{ }^{2-}$ resistance protein, namely AtTerC, has been detected that is also a thylakoid membrane protein involved in the assembly of photosystem II (PSII) in Arabidopsis thaliana. TerC seems to be a crucial protein, as its knockdown leads to the seedling-lethal phenotype [87]. TerC is a member of the YidC/Oxa1/Alb3 family. The homologues of this protein family are ubiquitously distributed in organisms. They function in bacteria, mitochondria and chloroplasts as membrane protein insertases. All homologues are involved in the insertion, folding and assembly of membrane proteins [88]. Predicted homologues of TerC are present in many bacteria, in plants and green algae and in some but not all cyanobacteria [89]. 
A summary of all $\mathrm{TeO}_{3}{ }^{2-}$ resistance mechanisms proposed to date is provided in Table 1. However, some of the mechanisms are not as yet supported by experimental evidence.

Table 1. Proposed putative tellurite $\left(\mathrm{TeO}_{3}{ }^{2-}\right)$ resistance mechanisms.

\begin{tabular}{|c|c|c|}
\hline Description of Considered Mechanism of Resistance & Organism & Reference \\
\hline $\begin{array}{l}\text { Inability to transport } \mathrm{TeO}_{3}{ }^{2-} \text { into the cell because of competitive inhibition of } \\
\mathrm{TeO}_{3}{ }^{2-} \text { by phosphate. } \mathrm{TeO}_{3}{ }^{2-} \text { is transported by phosphate transport pathway. }\end{array}$ & Escherichia coli & [57] \\
\hline $\begin{array}{l}\text { Oxidation-reduction steady-state mechanism among solid, soluble and volatile } \\
\text { gaseous Te species. } \mathrm{TeO}_{3}{ }^{2-} \text { conversion to volatile organic Te compounds. }\end{array}$ & $\begin{array}{l}\text { Rhodotorula spp. } \\
\text { Pseudoalteromonas spp. } \\
\text { Bacillus spp. }\end{array}$ & $\begin{array}{c}{[3]} \\
{[76]} \\
{[77]}\end{array}$ \\
\hline $\begin{array}{l}\text { Direct efflux of toxicant outside the cell. Acquisition of an efflux mechanism } \\
\text { facilitates the prevention of the intracellular accumulation of toxic compounds and } \\
\text { pumps molecules out of the cell. }\end{array}$ & Escherichia coli & $\begin{array}{l}{[20]} \\
{[59]}\end{array}$ \\
\hline Decreased influx and increased efflux is not responsible for the $\mathrm{K}_{2} \mathrm{TeO}_{3}$ resistance. & Escherichia coli & [65] \\
\hline Acetate transport system is responsible for uptake of $\mathrm{TeO}_{3}{ }^{2-}$ and resistance. & Rhodobacter capsulatus & $\begin{array}{l}{[60]} \\
{[38]}\end{array}$ \\
\hline $\begin{array}{c}\text { Enzymatic or nonenzymatic reduction of toxic } \mathrm{TeO}_{3}{ }^{2-}\left(\mathrm{Te}^{4+}\right) \text { to insoluble non/less } \\
\text { toxic elemental Te as crystals of } \mathrm{Te}^{0} \text {. The reduction } \mathrm{TeO}_{3}^{2-} \text { to } \mathrm{Te}^{0} \text { can also be } \\
\text { carried out by the activity of various types of cytoplasmic, periplasmic and/or } \\
\text { membrane-associated reductases. }\end{array}$ & $\begin{array}{c}\text { Staphylococcus aureus } \\
\text { Staphylococcus epidermidis } \\
\text { Pseudomonas aeruginosa } \\
\text { Escherichia coli } \\
\text { Rhodobacter sphaeroides } \\
\text { Bacillus spp. } \\
\text { Shewanella fridigimarina } \\
\text { Erythromonas ursincola }\end{array}$ & $\begin{array}{l}{[68]} \\
{[69]} \\
{[72]} \\
{[44]} \\
{[73]} \\
{[74]} \\
{[75]}\end{array}$ \\
\hline
\end{tabular}

\section{Tellurium Toxicity vs Potential Benefits for Prokaryotes and Eukaryotes}

\subsection{Impact of Tellurium Compounds on Organisms}

When Te compounds enter into cells, they can induce (I) changes in the integrity of cellular membrane structures [90], (II) changes in glutathione metabolism, (III) substitution of metal in enzymes and (IV) oxidative stress [91]. The common feature of these metal(loid)s is their chemical affinity to proteins and to non-protein thiols and their ability to generate cellular oxidative stress by the Fenton reaction. Oxidative stress is induced by their interaction with the cell thiolome [92,93], which represents the entity of the cellular thiol pool. Molecules carrying thiol groups are mostly derivatives of the amino acid cysteine and are called low molecular weight (LMW)-thiols: coenzyme A (CoA), glutathione (GSH) or bacillithiol (BSH). They serve to balance a reduced cell environment, act as cofactors in enzymatic reactions or help in the detoxification of reactive oxygen or nitrogen species, electrophilic compounds, or thiophilic metalloids $\left(\mathrm{AsO}_{3}{ }^{2-}, \mathrm{TeO}_{3}{ }^{2-}\right)$. Te oxyanions $\left(\mathrm{TeO}_{3}{ }^{2-}\right)$ are involved in the thiol: redox system of the cell and interfere with thiol: redox enzymes (glutathione reductase and thioredoxin reductase) and with their metabolites (glutathione, glutaredoxin and thioredoxin) [52]. The key target for $\mathrm{SeO}_{3}{ }^{2-}$ and $\mathrm{TeO}_{3}{ }^{2-}$ cellular processing is glutathione, which participates in $\mathrm{TeO}_{3}{ }^{2-}$ to $\mathrm{Te}\left(\mathrm{Te}^{0}\right)$ reduction [94] accompanied by reactive oxygen species (ROS) formation [95].

Glutathione is an endogenous tripeptide consisting of cysteine, glutamate and glycine and has antioxidative and other metabolic functions [96]. Glutathione and sodium glutathione are used to prevent neurotoxicity associated with cisplatin or oxaliplatin during cancer treatment and can also prevent adverse effects of antineoplastic and radiation therapy. They can additionally be used in the treatment of a wide range of other disorders including poisoning with heavy metals and other compounds and even in COVID-19 disease therapy [97]. The biosynthesis and metabolism of glutathione are directly related to stress tolerance. Noctor et al. [98] have demonstrated, in their review, that the metabolic pathway of glutathione biosynthesis consists of two sequential ATP-dependent reactions allowing the synthesis of $\gamma$-glutamylcysteine from L-glutamate and L-cysteine, followed 
by the formation of glutathione by the addition of glycine to the C-terminal end of $\gamma$ glutamylcysteine [99]. These reactions are catalysed by $\gamma$-glutamylcysteine synthetase and glutathione synthetase.

\subsection{Impact of Tellurium and Selenium on Humans}

The metabolic pathways involving Te, the mechanisms of its toxicity and its impact on human health, have been studied poorly to date. Te compounds can be taken in by inhalation or ingestion but neither pathway is often described. The clinical manifestation of the ingestion of metal-oxidizing solutions containing substantial concentrations of $\mathrm{Te}$ include vomiting, nausea, metallic taste, black discoloration of the oral mucosa and skin, corrosive gastrointestinal tract injury and a characteristic garlic-like odour of the breath [15]. As mentioned above, organotellurium compounds are, in general, less toxic than inorganic Te compounds. They have in part different pharmacological and pharmacokinetic profiles from each other, and they overcome different metabolic conversions in the human body. A few publications mention Te toxicity connected with microorganisms [20] and, thus, a possible bridge between microbial and human cells can reasonably be considered. One experimental observation is the analogy in the discoloration of skin versus that of bacterial cells. Phenotypic changes attributable to the reduction of $\mathrm{TeO}_{3}{ }^{2-}$ to elemental $\mathrm{Te}\left(\mathrm{Te}^{0}\right)$ are accompanied by the blackening of colonies and/or media as a consequence of the presence of nanocrystals or nanoparticle formation in the periplasmic space of cells [100]. Yarema and Curry [15] suggest that the phenomenon of discoloration of the skin is a result of the deposition of elemental Te in the dermis and subcutaneous tissue. Exposure to gaseous hydrogen telluride is different from exposure to other forms of Te. When exposure is limited, the mucous membrane and pulmonary system might become irritated. In animals, extensive exposure to hydrogen telluride have resulted in haemolysis, haemoglobinuria, anuria, jaundice and pulmonary oedema, symptoms similar to toxicity from the inhalation of arsine or the poisonous gas stibine [101]. The toxicity of Te, Se and As resides is associated with analogical secondary metabolite production, e.g., dimethyl telluride $\left(\left(\mathrm{CH}_{3}\right)_{2} \mathrm{Te}\right)$, dimethyl selenide $\left(\left(\mathrm{CH}_{3}\right)_{2} \mathrm{Se}\right)$ and monomethyl $\left(\mathrm{CH}_{3} \mathrm{AsO}(\mathrm{OH})_{2}\right)$ and dimethyl arsenic acid $\left(\left(\mathrm{CH}_{3}\right)_{2} \mathrm{AsO}_{2} \mathrm{H}\right)$, all of which have a characteristic garlic odour. Their toxicity is exerted via strong interaction with cysteine-containing proteins and enzymes [2].

The activity of many more enzymes is affected by Te compounds in animals. Experiments on rats and mice have revealed that, after $\mathrm{TeO}_{3}{ }^{2-}$ ingestion, the peripheral nerves become transiently demyelinated because of the inhibition of squalene epoxidase (squalene monooxygenase) [102]. This enzyme is involved in the biosynthesis of cholesterol, which is a crucial component of myelin. The mechanism of squalene epoxidase inhibition resides in the binding of methyltellurium compounds or $\mathrm{TeO}_{3}{ }^{2-}$ itself to the thiol groups of the cysteine residues at the active site [103]. Te atoms attack sulphur-containing cysteine-proteases, such as cathepsin B and caspases, which can lead to changes in cellular metabolism resulting in cell death via apoptosis. The same consequences can be observed after selenium-tellurium interaction in less abundant selenocysteine-containing biomolecules, such as selenoprotein P, thioredoxin reductase (TrxR) and various GPx enzymes [104]. Inhibition of these enzymes by interaction with Te compounds triggers a loss of antioxidant defence and widespread oxidative stress. Another group of enzymes affected by organotellurium compounds toxicity belongs to the glutamatergic system. Neurotoxic diphenyl ditelluride is able to alter enzymes of the glutamatergic system because of its interaction with the thiol groups of cysteine-containing enzymes and proteins [105]. The abovementioned group of enzymes use tellurium-sulphur chemistry to exert the toxicity of Te compounds. Tellurium-selenium interaction also has a significant effect on the activity of enzymes involved in Te toxicity. One member of this group is the human selenoenzyme thioredoxin reductase (TrxR), whose activity is modified by tellurium-selenium interaction [106]. These tellurium-sulphur and/or tellurium-selenium bonds can equally change the protein function and abolish normal enzymatic activity and can cause extensive damage 
to the cell via oxidative stress leading to cell death. Both Te compounds and Se compounds (I) weaken the cell's antioxidant defence (II) actively generating ROS.

The human body is known to metabolize and excrete Te, even if the exact metabolic pathways are not understood. However, a parallelism with the pathways of Se is apparent. After ingestion of $\mathrm{TeO}_{3}{ }^{2-}$ and $\mathrm{TeO}_{4}{ }^{2-}$, both are reduced in the liver. $\mathrm{TeO}_{3}{ }^{2-}$ is methylated resulting in dimethyltellurium $\left(\left(\mathrm{CH}_{3}\right)_{2} \mathrm{Te}\right)$ and finally trimethyltellurium $\left(\left(\mathrm{CH}_{3}\right)_{3} \mathrm{Te}^{+}\right)$. Dimethyltellurium can bind to haemoglobin, which then accumulates in the blood cells of the rat. This interaction resembles the action of arsenic [107]. Ba et al. [2] suggest that these methylated species are the most abundant forms of Te in the human body; they are found in the kidney, in the spleen and in the lungs. Finally, Te leaves the human body via urine and via breath as volatile $\left(\mathrm{CH}_{3}\right)_{2} \mathrm{Te}$, which is responsible for the garlic-like odour.

\section{Chemical Similarity of Tellurium to Selenium Determines Its Biology}

The chemical elements Te and Se are members of the chalcogen group, with Se forming part of the amino acid selenocysteine. The selenocysteine-containing biomolecules, are essential for the cell to resist oxidative stress condition [108]. Hence, Se is an essential trace element for both prokaryotic and eukaryotic biological systems at low concentrations but is toxic at higher levels [109].

The importance of naturally present trace elements in human food is undisputed. Mineral trace elements such as Se, zinc and copper are members of the group of micronutrients with antioxidative ability. Organic Se in food is found in selenomethionine and selenocysteine, whereas inorganic $\mathrm{Se}$ occurs as $\mathrm{SeO}_{3}{ }^{2-}$ (more toxic form) and selenate $\left(\mathrm{SeO}_{4}{ }^{2-}\right.$, less toxic form). These inorganic forms are mobile, toxic and water-soluble. The bioavailability of these compounds allows them to be easily absorbed by plants and animals from Se-rich soil or water. Thus, Se can enter the food chain and poses a potential threat to animals and humans [110,111].

High toxicities of Se and Te oxyanions cause environmental problems in contaminated soils and waters [112]. The ability of microorganisms to reduce Te and Se compounds in polluted and industrial areas is greatly appreciated in biometallurgy and bioremediation. These biotic methods involving the microbial retrieval of elements have become increasingly popular. Many bacterial strains have been described to be able to reduce these toxic oxyanions by producing elemental $\mathrm{Se}^{0} / \mathrm{Te}^{0}$ and by their ability to form nanoparticles containing $\mathrm{Se} / \mathrm{Te}$ as a result of detoxification. These nanoparticles have various shapes (nanospheres, nanorods, nanowires and nanotubes) [113], sizes and localisations (extracellular, intracellular). Duganella violacienigra can reduce both Se and Te oxyanions and so it can be exploited in bioremediation and in eco-friendly approaches to produce rare element nanoparticles, rather than synthesising them by chemical means [29]. Se, Te and other elements such as cadmium (Cd) and sulphur (S) are also used in the production of semiconductor nanoparticles (NPs) or quantum dots (QDs) with unique fluorescent properties and great technological potential [114,115]. Shewanella oneidensis MR-1 is another metalreducing bacterium that reduces $\mathrm{TeO}_{3}{ }^{2-}$ giving intracellularly accumulated needle-shaped crystalline $\mathrm{Te}^{0}$ nanorods. These metal-reducing bacteria, in general, play an important role in the recycling of toxic Te elements and can be applied as a novel selective biological filter for the cellular accumulation of industry-applicable rare elements such as $\mathrm{Te}^{0}$ nanorods [90]. Te-containing nanoparticles also exhibit antibacterial properties against $E$. coli, with no apparent cytotoxicity against eukaryotic cells [116]. These nanoparticles provide a huge field for research with potential applications in medicine, pharmacy, optic, metallurgy, chemistry and electronics. Not only are bacteria able to reduce Te, but other organisms such as plants or fungi are also able to accumulate toxic Te elements that can be applied as novel selective biological filters for use in bioremediation processes [90]. $\mathrm{SeO}_{3}{ }^{2-} / \mathrm{TeO}_{3}{ }^{2-}$ chemical similarity indicates they probably use the same pathway for the accumulation of Se in plants. The latter can proceed via several mechanisms, including phytoremediation, rhizofiltration, phytodegradation, phytostabilisation and phytovolatisation [117]. In connection with Te, plant accumulation from the soil is preferred and the further harvesting 
and absorption of Te from polluted water via plant roots for further decontamination holds promise [118]. Certain fungi can process Te compounds by biomethylation leading to the production of volatile dimethyltelluride $\left(\mathrm{CH}_{3}\right)_{2} \mathrm{Te}$, which is removed from organisms via evaporation [71]. The $\mathrm{NaTeO}_{3}$ presented in fungi medium without a sulphur source affects Te-containing amino acid production and consequently the formation of Te-containing protein with modified redox behaviour and catalytic activities [2].

Microorganisms, in general, play a crucial role in the biological transformation of $\mathrm{SeO}_{3}{ }^{2-}$ and $\mathrm{SeO}_{4}{ }^{2-}$ via metabolic reactions. The reduction of both forms, $\mathrm{SeO}_{3}{ }^{2-}$ and $\mathrm{SeO}_{4}{ }^{2-}$, to $\mathrm{Se}^{0}$ has been identified as an ideal strategy for Se detoxification and Se recovery in contaminated water, soil and industrial effluent [119]. A variety of microorganisms are used as microbial factories for the bioproduction of Se nanoparticles, e.g., Enterobacter cloacae [120], Bacillus cereus [121], Duganella sp., Agrobacterium sp. [122], Bacillus mycoides [123], Shewanella oneidensis [124], Pseudomonas putida [125] and Vibrio natriegens [126].

The concentration of Se in food depends on environmental conditions and thus its concentration in soil [127]. Bacteria can convert an inert form of elemental Se to soluble $\mathrm{SeO}_{3}{ }^{2-}$ and $/$ or $\mathrm{SeO}_{4}{ }^{2-}$. The food intake of nutrient antioxidants is therefore considerably reduced in comparison with recommendations in Europe. The best way to supplement food lacking antioxidants is their addition in an inorganic form or rather as selenoproteins. The yeasts Saccharomyces cerevisiae and bacterial strains Escherichia coli and Lactobacillus spp. can accumulate, metabolise and convert $\mathrm{SeO}_{3}{ }^{2-}$ and $\mathrm{SeO}_{4}{ }^{2-}$ into Se and incorporate it into cysteine and/or methionine [128]. The presence of $\mathrm{Se}^{0}$ in yeast cell structures has also been reported by Jiménez-Lamana et al. [129]. The various bacterial strains can also reduce and deposit metal(loid)s, e.g., Te and/or Se in a crystalline form [59]. Some acetic acid bacteria can produce an amorphous metabolizable form of Se or incorporate it into metalloproteins [130-132].

Since the chemistry of Te slightly resembles that of sulphur, Te can be incorporated into amino acids such as cysteine and methionine and subsequently into proteins and enzymes, as mentioned above. This incorporation does not require special machinery. It can occur naturally via bioincorporation [133]. Telluromethionine and tellurocysteine are suitable for highly sensitive fluorescent imaging methods as biomarkers. Te and its radioactive isotopes ${ }^{123 \mathrm{~m}} \mathrm{Te}$ can be synthesized as compounds with fatty acids. They are hardly metabolised but can be incorporated into the myocardium of experimental animals [134]. Te-containing fatty acids, Te-amino acids and many fluorescent Te particles (e.g., CdTe, CdSeTe, CdHgTe and $\mathrm{CdTe}-\mathrm{ZnTe}$ ) and nanoparticles are used as biomarkers for these imaging methods and could have potential applications as nanosensors [113].

Compared with Se-containing compounds (e.g., ebselen and selenocystamine), some of the tellurides are significantly effective compounds. Some of the organotellurium compounds exhibit promising antioxidant activity in cell culture. For example, 4,4'dihydroxydiphenyltelluride has turned out to be more protective in an (OS)-related model of Alzheimer's disease [135] in comparison with the Se-containing antioxidant ebselen, which is a synthetic organoselenium drug molecule with anti-inflammatory, antioxidant and cytoprotective activity. It acts as a mimic of glutathione peroxidase and can also react with peroxynitrite $\left(\mathrm{ONOO}^{-}\right)$[136]. Preliminary studies have demonstrated that ebselen exerts promising inhibitory activity against COVID-19 in cell-based assays. The effect has been attributed to irreversible inhibition of the Coronavirus Main Proteinase (3CL ${ }^{\text {pro }}$ ) via covalent bond formation with the thiol group of the cysteine (Cys-145) of the active centre [137]. The ability of water-soluble organotellurium compounds to catalyse the destruction of zinc-sulphur clusters in vivo has also been tested. Jacob et al. [135] suggest that these compounds might lead to the development of a new class of water-soluble Tebased antioxidant and Zn-releasing drugs. Synthetic organotellurium compounds such as bis(4-aminophenyl) telluride have potent antioxidative properties; bis(4-aminophenyl) telluride has higher glutathione peroxidase-like activity and protects against peroxynitritemediated oxidation more efficiently than its Se analogue or ebselen [138]. These organotel- 
lurium compounds have potential therapeutic properties as antioxidants and as regulators of Zn metabolism [135].

Inorganic salts of Te and a wide range of diverse organotellurium compounds show potential in diagnostics, pharmacology and therapy. They may provide the basis for innovative drug development in the future [2]. They are powerful agents in protein and enzyme inhibition, they can kill a wide range of microorganisms including bacteria and plasmodia and they are able to induce apoptosis of specific cancer cells.

Extreme environments are rarely distributed evenly over the Earth but they harbour a relatively high proportion of microorganisms considered valuable to science and technology [139], such as bacteria producing antibiotics [140] and bioactive molecules and bacteria useful in the biodegradation of pollutants [141]. Such environments provide habitats for representatives of various genera that possess the ability to resist and reduce elevated levels of toxic metal(loid)s compounds, specifically, Te compounds. These extreme environments are rich in heavy metals and metalloids and present excellent sites for the isolation of metal-resistant microorganisms.

\section{Conclusions and Perspectives}

Tellurium is a rare element with no apparent role in biological systems. Despite considerable advancement in the clarification of the biochemistry of tellurite metabolism tellurium function in biological systems as well as the molecular basis of tellurite toxicity, universal biomolecular mechanism of biochemical detoxification, mechanism of resistance and its interference with cellular processes, have not been elucidated to date and thus selenium can pass as a model.

Toxic chemicals, such as heavy metals or toxic compounds of some elements, can contribute to changes in human gut microbiota composition and metabolic profile due their uptake. It is important to understand in future works how these chemicals affect gut microbiota in relationship with metabolic and environmental diseases.

Author Contributions: Writing—original draft preparation, S.V. and E.S. contributed equally, S.S.; writing—review and editing, S.V., E.S., S.S.; supervision, J.T., S.S.; project administration, S.S.; funding acquisition, J.T., S.S. All authors have read and agreed to the published version of the manuscript.

Funding: The authors were supported by Slovak Research and Development Agency grant APVV17-0333 and ERDF project: SmartFarm No. ITMS2014: 313011V465.

Institutional Review Board Statement: Not applicable.

Informed Consent Statement: Not applicable.

Data Availability Statement: Not applicable.

Acknowledgments: The authors thank Jozef Mravec for critical manuscript reading.

Conflicts of Interest: The authors declare no conflict of interest.

\section{References}

1. Cooper, W.C. Tellurium; Van Nostrand Reinhold Company: New York, NY, USA, 1971; p. 34.

2. Ba, L.A.; Döring, M.; Jamier, V.; Jacob, C. Tellurium: An element with great biological potency and potential. Org. Biomol. Chem. 2010, 8, 4203-4216. [CrossRef]

3. Belzile, N.; Chen, Y.-W. Tellurium in the environment: A critical review focused on natural waters, soils, sediments and airborne particles. Appl. Geochem. 2015, 63, 83-92. [CrossRef]

4. Jabłońska-Czapla, M.; Grygoyć, K. Speciation and Fractionation of Less-Studied Technology-Critical Elements (Nb, Ta, Ga, In, Ge, Tl, Te): A Review. Pol. J. Environ. Stud. 2021, 30, 1477-1486. [CrossRef]

5. Filella, M.; Reimann, C.; Biver, M.; Rodushkin, I.; Rodushkina, K. Tellurium in the environment: Current knowledge and identification of gaps. Environ. Chem. 2019, 16, 215-228. [CrossRef]

6. Jabłońska-Czapla, M.; Grygoyć, K. Development of a Tellurium Speciation Study Using IC-ICP-MS on Soil Samples Taken from an Area Associated with the Storage, Processing, and Recovery of Electrowaste. Molecules 2021, 26, 2651. [CrossRef]

7. BGS. London Earth Surface Soil G-BASE Dataset. (British Geological Survey: Keyworth). 2011. Available online: www.bgs.ac.uk/ gbase/londonearth.html (accessed on 27 May 2021). 
8. Cunha, R.L.; Gouvea, I.E.; Juliano, L. A glimpse on biological activities of tellurium compounds. An. Acad. Bras. Ciênc. 2009, 81, 393-407. [CrossRef]

9. Presentato, A.; Turner, R.J.; Vásquez, C.C.; Yurkov, V.; Zannoni, D. Tellurite-dependent blackening of bacteria emerges from the dark ages. Environ. Chem. 2019, 16, 266-288. [CrossRef]

10. Green, M.A. Estimates of Te and in prices from direct mining of known ores. Prog. Photovolt Res. Appl. 2009, 17, 347-359. [CrossRef]

11. Wray, D.S. The impact of unconfined mine tailings and anthropogenic pollution on a semi-arid environment-an initial study of the Rodalquilar mine district, south east Spain. Environ. Geochem. Health 1998, 20, 29-38. [CrossRef]

12. Hein, J.R.; Koschinsky, A.; Halliday, A.N. Global occurrence of tellurium- rich ferromanganese crusts and a model for the enrichment of tellurium. Geochim. Cosmochim. Acta 2003, 67, 1117-1127. [CrossRef]

13. Ullal, H.S.; von Roedern, B. Thin film CIGS and CdTe photovoltaic technologies: Commercialization, Critical Issues, and Applications. In Proceedings of the 22nd European Photovoltaic Solar Energy Conference (PVSEC) and Exhibition, Milan, Italy, 3-7 September 2007.

14. Kraemer, D.; Poudel, B.; Feng, H.P.; Caylor, J.C.; Yu, B.; Yan, X.; Ma, Y.; Wang, X.; Wang, D.; Muto, A.; et al. High-performance flat-panel solar thermoelectric generators with high thermal concentration. Nat. Mater. 2011, 10, 532-538. [CrossRef]

15. Yarema, M.C.; Curry, S.C. Acute tellurium toxicity from ingestion of metal-oxidizing solutions. Pediatrics 2005, 116, 319-321. [CrossRef]

16. Ikeda, H.; Fujino, S.; Kajiwara, T. Preparation and characterization of $\mathrm{BaO}-\mathrm{TeO}_{2}$ thin films obtained from tellurium(VI) alkoxide by a Sol-Gel method. J. Am. Ceram. Soc. 2009, 92, 2619-2622. [CrossRef]

17. Graf, C.; Assoud, A.; Mayasree, O.; Kleinke, H. Solid state polyselenides and polytellurides: A large variety of Se-Se and Te-Te interactions. Molecules 2009, 14, 3115-3131. [CrossRef]

18. Sandoval, J.M.; Levêque, P.; Gallez, B.; Vasquez, C.C.; Buc Calderon, P. Tellurite-induced oxidative stress leads to cell death of murine hepatocarcinoma cells. Biometals 2010, 23, 623-632. [CrossRef]

19. Perez-D'Gregorio, R.E.; Miller, R.K. Teratogenicity of tellurium dioxide: Prenatal assessment. Teratology 1988, 37, 307-316. [CrossRef]

20. Chasteen, T.G.; Fuentes, D.E.; Tantaleán, J.; Vásquez, C.C. Tellurite: History, oxidative stress, and molecular mechanisms of resistance. FEMS Microbiol. Rev. 2009, 33, 820-832. [CrossRef]

21. Taylor, D.E. Bacterial tellurite resistance. Trends Microbiol. 1999, 7, 111-115. [CrossRef]

22. Cox, P. The Elements, 1st ed.; Oxford University Press: New York, NY, USA, 1989.

23. Carmely, A.; Meirow, D.; Peretz, A.; Albeck, M.; Bartoov, B.; Sredni, B. Protective effect of the immunomodulator AS101 against cyclophosphamide-induced testicular damage in mice. Hum. Reprod. 2009, 24, 1322-1329. [CrossRef]

24. Giles, G.I.; Tasker, K.M.; Johnson, R.J.K.; Jacob, C.; Peers, C.; Green, K.N. Electrochemistry of chalcogen compounds: Prediction of antioxidant activity. Protective effect of the immunomodulator AS101 against cyclophosphamide-induced testicular damage in mice. Chem. Commun. 2001, 2490-2491. [CrossRef]

25. Giles, G.I.; Giles, N.M.; Collins, C.A.; Holt, K.; Fry, F.H.; Lowden, P.A.S.; Gutowski, N.J.; Jacob, C. Electrochemical, in vitro and cell culture analysis of integrated redox catalysts: Implications for cancer therapy. Chem. Commun. 2003, 16, 2030-2031. [CrossRef]

26. Kumar, S.; Johansson, H.; Kanda, T.; Engman, L.; Muller, T.; Bergenudd, H.; Jonsson, M.; Pedulli, G.F.; Amorati, R.; Valgimigli, L. Catalytic chain-breaking pyridinol antioxidants. J. Org. Chem. 2010, 75, 716-725. [CrossRef] [PubMed]

27. Summers, A.O.; Jacoby, G.A. Plasmid-determined resistance of tellurium compounds. J. Bacteriol. 1977, 129, 276-281. [CrossRef]

28. Turner, R.J.; Weiner, J.H.; Taylor, D.E. Tellurite mediated thiol oxidation in Escherichia coli. Microbiology 1999, 145, $2549-2557$. [CrossRef]

29. Bajaj, M.; Winter, J. Se (IV) triggers faster Te (IV) reduction by soil isolates of heterotrophic aerobic bacteria: Formation of extracellular SeTe nanospheres. Microb. Cell Fact. 2014, 13, 168. [CrossRef]

30. Fleming, A. On the specific antibacterial properties of penicillin and potassium tellurite. Incorporating a method of demonstrating some bacterial antagonisms. J. Pathol. Bacteriol. 1932, 35, 831-842. [CrossRef]

31. Kinraide, T.B.; Yermiyahu, U. A scale of metal ion binding strengths correlating with ionic charge, Pauling electronegativity, toxicity, and other physiological effects. J. Inorg. Biochem. 2007, 101, 1201-1213. [CrossRef]

32. Moroder, L. Isoteric replacement of sulfur with other chalcogens in peptides and proteins. J. Pept. Sci. 2005, 11, 187-214. [CrossRef]

33. Lohmeir-Vogel, E.; Ung, S.; Turner, R. In vivo 31P nuclear magnetic resonance investigation of tellurite toxicity in Escherichia coli. Appl. Environ. Microbiol. 2004, 70, 7324-7347. [CrossRef]

34. Burkholz, T.; Jacob, C. Tellurium in nature. In Encyclopedia of Metalloproteins, 1st ed.; Kretsinger, R.H., Uversky, V.N., Permyakov, E.A., Eds.; Springer: New York, NY, USA, 2013; pp. 2163-2174.

35. Maltman, C.; Yurkov, V. The effect of tellurite on highly resistant freshwater aerobic anoxygenic phototrophs and their strategies for reduction. Microorganisms 2015, 3, 826-838. [CrossRef]

36. Moore, M.D. Members of the family Rhodospirillaceae reduce heavy-metal oxyanions to maintain redox poise during photosynthetic growth. ASM News 1994, 60, 17-23. 
37. Csotonyi, J.; Maltman, C.; Swiderski, J.; Stackenbrandt, E.; Yurkov, V. Extremely "vanadiphilic" multiply metal-resistant and halophilic aerobic anoxygenic phototrophs, strains EG13 and EG8, from hypersaline springs in Canada. Extremophiles 2015, 19, 127-134. [CrossRef] [PubMed]

38. Moore, M.; Kaplan, S. Identification of intrinsic high-level resistance to rare-earth oxides and oxyanions in members of the class Proteobacteria: Characterization of tellurite, selenite, and rhodium sesquioxide reduction in Rhodobacter sphaeroides. J. Bacteriol. 1992, 174, 1505-1514. [CrossRef] [PubMed]

39. Taylor, D.E.; Rooker, M.; Keelan, M.; Ng, L.K.; Martin, I.; Perna, N.T.; Burland, N.T.; Blattner, F.R. Genomic variability of O islands encoding tellurite resistance in enterohemorrhagic Escherichia coli O157:H7 isolates. J. Bacteriol. 2002, 184, 4690-4698. [CrossRef] [PubMed]

40. Perry, J.D. A decade of development of chromogenic culture media for clinical microbiology in an era of molecular diagnostics. Clin. Microbiol. Rev. 2017, 30, 449-479. [CrossRef]

41. Blaskovic, D.; Turna, J. Tellurite-reduction-based assay for screening potential antibiotics. J. Medic. Microbiol. 2012, 61, 160-161. [CrossRef]

42. Maltman, C.; Yurkov, V. Extreme environments and high-level bacterial tellurite resistance. Microorganisms 2019, 7, 601. [CrossRef]

43. Fernández, L.; Hancock, R.E.W. Adaptive and mutational resistance: Role of porins and efflux pumps in drug resistance. Clin. Microbiol. Rev. 2012, 25, 661-681. [CrossRef]

44. Baquero, F. Low-level antibacterial resistance: A gateway to clinical resistance. Drug Resist. Update 2001, 4, 93-105. [CrossRef]

45. Fernández, L.; Breidenstein, E.B.M.; Hancock, R.E.W. Creeping baselines and adaptive resistance to antibiotics. Drug Resist. Update 2011, 14, 1-21. [CrossRef]

46. Arenas, F.; Pugin, B.; Henríquez, N.; Arenas, M.; Díaz, W.; Pozo, F.; Muñoz, C.M.; Chasteen, T.G.; Pérez-Donoso, J.M.; Vásquez, C.C. Isolation, identification and characterization of highly tellurite-resistant, tellurite-reducing bacteria from Antarctica. Polar Sci. 2014, 8, 40-52. [CrossRef]

47. Coombs, J.; Barkay, T. Molecular evidence for the evolution of metal homeostasis genes by lateral gene transfer in bacteria from the deep terrestrial subsurface. Appl. Environ. Microbiol. 2003, 70, 1698-1707. [CrossRef]

48. Daubin, V.; Gouy, M.; Perriere, G. A phylogenomic approach to bacterial phylogeny: Evidence of a core of genes sharing a common history. Genom. Res. 2002, 12, 1080-1090. [CrossRef]

49. Tomas, J.M.; Kay, W.W. Tellurite susceptibility and non-plasmid-mediated resistance in Escherichia coli. Antimicrob. Agents. Chemother. 1986, 30, 127-131. [CrossRef]

50. Elias, A.; Abarca, M.; Montes, R.; Chasteen, T.; Perez-Donoso, J.; Vasquez, C. Tellurite enters Escherichia coli mainly through the PitA phosphate transporter. Microbiologyopen 2012, 1, 259-267. [CrossRef]

51. Foster, T.J. Plasmid-determined resistance to antimicrobial drugs and toxic metal ions in bacteria. Microbiol. Rev. 1983, 47, 361-409. [CrossRef]

52. Turner, R.J.; Weiner, J.H.; Taylor, D.E. Neither reduced uptake nor increased efflux is encoded by tellurite resistance determinants expressed in Escherichia coli. Can. J. Microbiol. 1995, 41, 92-98. [CrossRef] [PubMed]

53. Borghese, R.; Zannoni, D. Acetate permease (ActP) is responsible for tellurite $\left(\mathrm{TeO}_{3}{ }^{2-}\right)$ uptake and resistance in cells of the facultative phototroph Rhodobacter capsulatus. Appl. Environ. Microbiol. 2010, 76, 942-944. [CrossRef]

54. Borghese, R.; Canducci, L.; Musiani, F.; Cappelletti, M.; Ciurli, S.; Rurner, R.; Zannoni, D. On the role of a specific insert in acetate permease (ActP) for tellurite uptake in bacteria: Functional and structural studies. J. Inorg. Biochem. 2016, 163, 103-109. [CrossRef] [PubMed]

55. Tremaroli, V.; Fedi, S.; Zannoni, D. Evidence for a tellurite-dependent generation of reactive oxygen species and absence of a tellurite-mediated adaptive response to oxidative stress in cells of Pseudomonas pseudoalcaligenes KF707. Arch. Microbiol. 2007, 187, 127-135. [CrossRef] [PubMed]

56. Klett, A. Zur Kenntniss der reducirenden Eigenschaften der Bakterien. Z. Hyg. Infectionskrank. 1900, 33, 137-160. [CrossRef]

57. Scheurlen, Die Verwendung der selenigen und tellurigen Säure in der Bakteriologie. Z. Hyg. Infektionskr. 1900, 33, $135-136$. [CrossRef]

58. Yurkov, V.; Jappe, J.; Vermeglio, A. Tellurite resistance and reduction by obligately aerobic photosynthetic bacteria. Appl. Environ. Microbiol. 1996, 62, 4195-4198. [CrossRef] [PubMed]

59. Burian, J.; Tu, N.; Klucar, L.; Guller, L.; Lloyd-Jones, G.; Stuchlik, S.; Fejdi, P.; Siekel, P.; Turna, J. In vivo and in vitro cloning and phenotype characterization of tellurite resistance determinant conferred by plasmid pTE53 of a clinical isolate of Escherichia coli. Folia Microbiol. 1998, 43, 589-599. [CrossRef] [PubMed]

60. Avazeri, C.; Turner, R.; Pommier, J.; Weiner, J.; Giordana, G.; Vermeglio, A. Tellurite reductase activity of nitrate reductase is responsible for the basal resistance of Escherichia coli to tellurite. Microbiology 1997, 143, 1181-1189. [CrossRef]

61. Harrison, S. Whither structural biology? Nat. Struct. Mol. Biol. 2004, 11, 12-15. [CrossRef]

62. Borsetti, F.; Francia, F.; Turner, R.; Zannoni, D. The thiol:disulfide oxidoreductase DsbB mediates the oxidizing effects of the toxic metalloid tellurite $\left(\mathrm{TeO}_{3}{ }^{2-}\right)$ on the plasma membrane redox system of the facultative phototroph Rhodobacter capsulatus. J. Bacteriol. 2007, 189, 851-859. [CrossRef]

63. Guzzo, J.; Dubow, M. A novel selenite- and tellurite inducible gene in Escherichia coli. Appl. Environ. Microbiol. 2000, 66, 4972-4978. [CrossRef] 
64. Calderon, I.; Arenas, F.; Perez, J.; Fuentes, D.; Araya, M.; Saavedra, C.; Tantalean, J.; Pichuantes, S.; Youderian, P.; Vasquez, C. Catalases are NAD(P)H-dependant tellurite reductases. PLoS ONE 2006, 1, 1-8. [CrossRef]

65. Sabaty, M.; Avazeri, C.; Pignol, D.; Vermeglio, A. Characterization of the reduction of selenate and tellurite by nitrate reductases. Appl. Environ. Microbiol. 2001, 67, 5122-5126. [CrossRef]

66. Soudi, M.; Ghazvini, P.; Khajeh, K.; Gharavi, S. Bioprocessing of seleno-oxyanions and tellurite in a novel Bacillus sp. strain STG-83: A solution to removal of toxic oxyanions in the presence of nitrate. J. Hazard. Mater. 2009, 165, 71-77. [CrossRef]

67. Etezad, S.M.; Khajeh, K.; Soudi, M.; Ghazvini, P.T.M.; Dabirmanesh, B. Evidence on the presence of two distinct enzymes responsible for the reduction of selenate and tellurite in Bacillus sp. STG-83. Enzym. Microb. Technol. 2009, 45, 1-6. [CrossRef]

68. Maltman, C.; Donald, L.; Yurkov, V. Two distinct periplasmic enzymes are responsible for tellurite/tellurate and selenite reduction by strain ER-Te-48 isolated from a deep sea hydrothermal vent tube worms at the Juan de Fuca Ridge black smokers. Arch. Microbiol. 2017, 199, 1113-1120. [CrossRef]

69. Maltman, C.; Donald, L.; Yurkov, V. Tellurite and tellurate reduction by the aerobic anoxygenic phototroph Erythromonas ursincola, strain KR99 is carried out by a novel membrane associated enzyme. Microorganisms 2017, 5, 20. [CrossRef] [PubMed]

70. Bonificio, W.D.; Clarke, D.R. Bacterial recovery and recycling of tellurium from tellurium-containing compounds by Pseudoalteromonas sp. EPR3. J. Appl. Microbiol. 2014, 117, 1293-1304. [CrossRef] [PubMed]

71. Chasteen, T.G.; Bentley, R. Biomethylation of selenium and tellurium: Microorganisms and plants. Chem. Rev. 2003, 103, 1-25. [CrossRef]

72. Ollivier, P.; Bahrou, A.; Marcus, S.; Cox, T.; Church, T.; Hanson, T. Volitization and precipitation of tellurium by aerobic tellurite-resistant marine microbes. Appl. Environ. Microbiol. 2008, 74, 7163-7173. [CrossRef]

73. Ogra, Y. Toxicometallomics for research on the toxicology of exotic metalloids based on speciation studies. Anal. Sci. 2009, 25, 1189-1195. [CrossRef]

74. Jobling, M.G.; Ritchie, D.A. Genetic and physical analysis of the plasmid genes expressing inducible resistance to tellurite in Escherichia coli. Mol. Gen. Genet. 1987, 208, 288-293. [CrossRef]

75. Whelan, K.F.; Colleran, E.; Taylor, D.E. Phage inhibition, colicin resistance and tellurite resistance are encoded by a single cluster of genes on the IncHI2 plasmid R478. J. Bacteriol. 1995, 177, 5016-5027. [CrossRef]

76. Chen, Y.T.; Chang, H.Y.; Lai, Y.C.; Pan, C.C.; Tsai, S.F.; Peng, H.L. Sequencing and analysis of the large virulence plasmid pLVPK of Klebsiella pneumoniae CG43. Gene 2004, 337, 189-198. [CrossRef]

77. Soltys, K.; Vavrova, S.; Budis, J.; Palkova, L.; Minarik, G.; Grones, J. Draft genome sequence of Escherichia coli KL53. Genom. Announc. 2018, 6. [CrossRef]

78. Kormutakova, R.; Klucar, L.; Turna, J. DNA sequence analysis of the tellurite-resistance determinant from clinical strain of Escherichia coli and identification of essential genes. Biometals 2000, 13, 135-139. [CrossRef]

79. Perna, N.T.; Plunket, G.; Burland, V.; Mau, B.; Glasner, J.D.; Rose, D.J.; Mayhew, G.F.; Evans, P.S.; Gregor, J.; Kirkpatrick, H.A.; et al. Genome sequence of enterohaemorrhagic Escherichia coli O157:H7. Nature 2001, 409, 529-533. [CrossRef]

80. Hayashi, T.; Makino, K.; Ohnishi, M.; Kurokawa, K.; Ishii, K.; Yokoyama, K.; Han, C.G.; Ohtsubo, E.; Nakayama, K.; Murata, T.; et al. Complete genome sequence of enterohemorrhagic Escherichia coli O157:H7 and genomic comparison with a laboratory strain K-12. DNA Res. 2001, 8, 11-22. [CrossRef] [PubMed]

81. Hacker, J.; Carniel, E. Ecological fitness, genomic islands and bacterial pathogenicity. EMBO Rep. 2001, 21, 376-381. [CrossRef] [PubMed]

82. Zadik, P.M.; Chapman, P.A.; Siddons, C.A. Use of tellurite for the selection of verocytotoxigenic Escherichia coli O157. J. Med. Microbiol. 1993, 39, 155-158. [CrossRef]

83. Rathgeber, C.; Yurkova, N.; Stackebrandt, E.; Beatty, J.T.; Yurkov, V. Isolation of tellurite- and selenite-resistant bacteria from hydrothermal vents of the Juan de Fuca Ridge in the Pacific Ocean. Appl. Environ. Microbiol. 2002, 68, 4613-4622. [CrossRef] [PubMed]

84. Ponnusamy, D.; Clinkenbeard, K.D. Role of tellurite resistance operon in filamentous growth of Yersinia pestis in macrophages. PLoS ONE 2015, 10, e0141984. [CrossRef] [PubMed]

85. Muñoz-Villagrán, C.M.; Mendez, K.N.; Cornejo, F.; Figueroa, M.; Undabarrena, A.; Morales, E.H.; Arenas-Salinas, M.; Arenas, F.A.; Castro-Nallar, E.; Vásquez, C.C. Comparative genomic analysis of a new tellurite-resistant Psychrobacter strain isolated from the Antarctic Peninsula. Peer] 2018, 6, e4402. [CrossRef]

86. Wu, S.; Li, T.; Xia, X.; Zhou, Z.; Zheng, S.; Wang, G. Reduction of tellurite in Shinella sp. WSJ-2 and adsorption removal of multiple dyes and metals by biogenic tellurium nanorods. Int. Biodeterior. Biodegrad. 2019, 144, 104751. [CrossRef]

87. Schneider, A.; Steinberger, I.; Strissel, H.; Kunz, H.H.; Manavski, N.; Meurer, J.; Burkhard, G.; Jarzombski, S.; Schünemann, D.; Geimer, S.; et al. The Arabidopsis tellurite resistance C protein together with ALB3 is involved in photosystem II protein synthesis. Plant J. 2014, 78, 344-356. [CrossRef]

88. Funes, S.; Kauff, F.; van der Sluis, E.O.; Ott, M.; Herrmann, J.M. Evolution of YidC/Oxa1/Alb3 insertases: Three independent gene duplications followed by functional specialization in bacteria, mitochondria and chloroplasts. Biol. Chem. 2011, 392, 13-19. [CrossRef]

89. Kwon, K.-C.; Cho, M.H. Deletion of the chloroplast-localized AtTerC gene product in Arabidopsis thaliana leads to loss of the thylakoid membrane and to seedling lethality. Plant J. 2008, 55, 428-442. [CrossRef] 
90. Kim, D.H.; Kanaly, R.A.; Hur, H.G. Biological accumulation of tellurium nanorod structures via reduction of tellurite by Shewanella oneidensis MR-1. Biores. Technol. 2012, 125, 127-131. [CrossRef]

91. Valdivia-González, M.; Perez-Donoso, J.M.; Vásquez, C.C. Effect of tellurite-mediated oxidative stress on the Escherichia coli glycolytic pathway. Biometals 2012, 25, 451-458. [CrossRef]

92. Kell, D.B. Towards a unifying, systems biology understanding of large-scale cellular death and destruction caused by poorly liganded iron: Parkinson's, Huntington's, Alzheimer's, prions, bactericides, chemical toxicology and others as examples. Arch. Toxicol. 2010, 84, 825-889. [CrossRef] [PubMed]

93. Rubino, F.M. Toxicity of glutathione-binding metals: A review of targets and mechanisms. Toxics 2015, 3, 20-62. [CrossRef] [PubMed]

94. Turner, R.J.; Aharonowitz, Y.; Weiner, J.H.; Taylor, D.E. Glutathione is a target in tellurite toxicity and is protected by tellurite resistance determinants in Escherichia coli. Can. J. Microbiol. 2001, 47, 33-40. [CrossRef] [PubMed]

95. Kessi, J.; Hanselmann, K.W. Similarities between the abiotic reduction of selenite with glutathione and the dissimilatory reaction mediated by Rhodospirillum rubrum and Escherichia coli. J. Biol. Chem. 2004, 279, 50662-50669. [CrossRef]

96. Hopkins, F.G. On glutathione, a reinvestigation. J. Biol. Chem. 1929, 84, 269-320. [CrossRef]

97. Horowitz, R.I.; Freeman, P.R.; Bruzzese, J. Efficacy of glutathione therapy in relieving dyspnea associated with COVID-19 pneumonia: A report of 2 cases. Respir. Med. Case Rep. 2020, 21, 101063. [CrossRef]

98. Noctor, G.; Arisi, A.-C.M.; Jouanin, L.; Kunert, K.J.; Rennenberg, H.; Foyer, C.H. Glutathione: Biosynthesis, metabolism, and relationship to stress tolerance explored in transformed plants. J. Exp. Bot. 1998, 49, 623-647. [CrossRef]

99. Meister, A. Glutathione metabolism and its selective modification. J. Biol. Chem. 1988, 263, 17205-17208. [CrossRef]

100. Turner, R.J.; Borghese, R.; Zannoni, D. Microbial processing of tellurium as a tool in biotechnology. Biotechnol. Adv. 2012, 30, 954-963. [CrossRef]

101. Cerwenka, E.A.J.; Cooper, W.C. Toxicology of selenium and tellurium and their compounds. Arch. Environ. Health. 1961, 3 , 189-200. [CrossRef]

102. Abe, I.; Abe, T.; Lou, W.; Masuoka, T.; Noguchi, H. Site-directed mutagenesis of conserved aromatic residues in rat squalene epoxidase. Biochem. Biophys. Res. Commun. 2007, 352, 259-263. [CrossRef]

103. Laden, B.P.; Porter, T.D. Inhibition of human squalene monooxygenase by tellurium compounds: Evidence of interaction with vicinal sulfhydryls. J. Lipid. Res. 2001, 42, 235-240. [CrossRef]

104. Garberg, P.; Engman, L.; Tolmachev, V.; Lundqvist, H.; Gerdes, R.G.; Cotgreave, I.A. Binding of tellurium to hepatocellular selenoproteins during incubation with inorganic tellurite: Consequences for the activity of selenium-dependent glutathione peroxidase. Int. J. Biochem. Cell. Biol. 1999, 31, 291-301. [CrossRef]

105. Stangherlin, E.C.; Ardais, A.P.; Rocha, J.B.T.; Nogueira, C.W. Exposure to diphenyl ditelluride, via maternal milk, causes oxidative stress in cerebral cortex, hippocampus and striatum of young rats. Arch. Toxicol. 2009, 83, 485-491. [CrossRef]

106. McNaughton, M.; Engman, L.; Birmingham, A.; Powis, G.; Cotgreave, I.A. Cyclodextrin-derived diorganyl tellurides as glutathione peroxidase mimics and inhibitors of thioredoxin reductase and cancer cell growth. J. Med. Chem. 2004, 47, 233-239. [CrossRef]

107. Kobayashi, A.; Ogra, Y. Metabolism of tellurium, antimony and germanium simultaneously administered to rats. J. Toxicol. Sci. 2009, 34, 295-303. [CrossRef] [PubMed]

108. Sunde, R.A. Molecular biology of selenoproteins. Annu. Rev. Nutr. 1990, 10, 451-474. [CrossRef] [PubMed]

109. Kessi, J.; Ramuz, M.; Wehrli, E.; Spycher, M.; Bachofen, R. Reduction of selenite and detoxification of elemental selenium by the phototrophic bacterium Rhodospirillum rubrum. Appl. Environ. Microbiol. 1999, 65, 4734-4740. [CrossRef] [PubMed]

110. Whanger, P.D. Selenocompounds in plants and animals and their biological significance. J. Am. Coll. Nutr. 2002, $21,223-232$. [CrossRef]

111. Sors, T.G.; Ellis, D.R.; Salt, D.E. Selenium uptake, translocation, assimilation and metabolic fate in plants. Photosynth. Res. 2005, 86, 373-389. [CrossRef]

112. Harada, T.; Takahashi, Y. Origin of the difference in the distribution behavior of tellurium and selenium in a soil-water system. Geochim. Cosmochim. Ac. 2009, 72, 1281-1294. [CrossRef]

113. Wang, Z.; Wang, L.; Huang, J.; Wang, H.; Pan, L.; Wei, X. Formation of single-crystal tellurium nanowires and nanotubes via hydrothermal recrystallization and their gas sensing properties at room temperature. J. Mater. Chem. 2010, 20, $2457-2463$. [CrossRef]

114. Deng, Z.; Zhang, Y.; Yue, J.; Tang, F.; Wei, Q. Green and orange CdTe quantum dots as effective pH-sensitive fluorescent probes for dual simultaneous and independent detection of viruses. J. Phys. Chem. B 2007, 111, 12024-12031. [CrossRef]

115. Monrás, J.P.; Collao, B.; Molina-Quiroz, R.C.; Pradenas, G.A.; Saona, L.A.; Durán-Toro, V.; Ordenes-Aenishanslins, N.; Venegas, F.A.; Loyola, D.E.; Bravo, D.; et al. Microarray analysis of the Escherichia coli response to CdTe-GSH Quantum Dots: Understanding the bacterial toxicity of semiconductor nanoparticles. BMC Genom. 2014, 15, 1099. [CrossRef]

116. Pugin, B.; Cornejo, F.A.; Muñoz-Díaz, P.; Muñoz-Villagrán, C.M.; Vargas-Pérez, J.I.; Arenas, F.A.; Vásquez, C.C. Glutathione reductase-mediated synthesis of tellurium-containing nanostructures exhibiting antibacterial properties. Appl. Environ. Microbiol. 2014, 80, 7061-7070. [CrossRef]

117. Babula, P.; Adam, V.; Opatrilova, R.; Zehnalek, J.; Havel, L.; Kizek, R. Uncommon heavy metals, metalloids and their plant toxicity: A review. Environ. Chem. Lett. 2008, 6, 189-213. [CrossRef] 
118. Ródenas-Torralba, E.; Cava-Montesinos, P.; Morales-Rubio, A.; Cervera, M.L.; De La Guardia, M. Multicommutation as an environmentally friendly analytical tool in the hydride generation atomic fluorescence determination of tellurium in milk. Anal. Bioanal. Chem. 2004, 379, 83-89. [CrossRef]

119. Nancharaiah, Y.V.; Lens, P.N.L. Selenium biomineralization for biotechnological applications. Trends Biotechnol. 2015, 33, 323-330. [CrossRef]

120. Yee, N.; Ma, J.; Dalia, A.; Boonfueng, T.; Kobayashi, D. Se(VI) reduction and the precipitation of Se(0) by the facultative bacterium Enterobacter cloacae SLD1a-1 are regulated by FNR. Appl. Environ. Microbiol. 2007, 73, 1914-1920. [CrossRef]

121. Dhanjal, S.; Cameotra, S.S. Aerobic biogenesis of selenium nanospheres by Bacillus cereus isolated from coalmine soil. Microb. Cell Fact. 2010, 9, 52. [CrossRef] [PubMed]

122. Bajaj, M.; Schmidt, S.; Winter, J. Formation of Se(0) nanoparticles by Duganella sp. and Agrobacterium sp. isolated from Se-laden soil of north-east Punjab, India. Microb. Cell Fact. 2012, 13, 168. [CrossRef] [PubMed]

123. Lampis, S.; Zonaro, E.; Bertolini, C.; Bernardi, P.; Butler, C.S.; Vallini, G. Delayed formation of zero-valent selenium nanoparticles by Bacillus mycoides SelTE01 as a consequence of selenite reduction under aerobic conditions. Microb. Cell Fact. 2014, 13, 35 [CrossRef]

124. Li, D.B.; Cheng, Y.Y.; Wu, C.; Li, W.W.; Li, N.; Yang, Z.C.; Tong, Z.H.; Yu, H.Q. Selenite reduction by Shewanella oneidensis MR-1 is mediated by fumarate reductase in periplasm. Sci. Rep. 2014, 4, 3735. [CrossRef] [PubMed]

125. Avendaño, R.; Chaves, N.; Fuentes, P.; Sánchez, E.; Jiménez, J.I.; Chavarría, M. Production of selenium nanoparticles in Pseudomonas putida KT2440. Sci. Rep. 2016, 6, 37155. [CrossRef]

126. Fernández-Llamosas, H.; Castro, L.; Blázquez, M.L.; Díaz, E.; Carmona, M. Speeding up bioproduction of selenium nanoparticles by using Vibrio natriegens as microbial factory. Sci. Rep. 2017, 7, 16046. [CrossRef]

127. Geering, H.R.; Cary, E.E.; Jones, L.H.P.; Allaway, W.H. Solubility and redox criteria for the possible forms of selenium in soils. Soil Sci. Soc. Am. Proc. 1968, 32, 35-47. [CrossRef]

128. Kieliszek, M.; Błazejak, S.; Gientka, I.; Bzducha-Wróbel, A. Accumulation and metabolism of selenium by yeast cells. Appl. Microbiol. Biotechnol. 2015, 99, 5373-5382. [CrossRef]

129. Jiménez-Lamana, J.; Abadálvaro, I.; Bierla, K.; Laborda, F.; Szpunar, J.; Lobinski, R. Detection and characterization of biogenic selenium nanoparticles in selenium-rich yeast by single particle ICPMS. J. Anal. At. Spectrom. 2018, 33, 452-460. [CrossRef]

130. Grones, J.; Macor, M.; Siekel, P.; Bilska, V. Capability of Escherichia coli and Lactobacillus spp. to accumulate selenium in a biologically utilisable form. Bull. Food Res. 1999, 38, 45-53.

131. Macor, M.; Grones, J. Genetic basis of selenium incorporation into proteins in bacterial cells. Bull. Food Res. 2001, 40, 101-118.

132. Macor, M.; Kretova, M.; Korenovska, M.; Siekel, P.; Grones, J. Utilisation of selenium and distribution into bacterial cell structures. Bull. Food Res. 2003, 42, 205-212.

133. Liu, X.; Silks, L.A.; Liu, C.; Ollivault-Shiflett, M.; Huang, X.; Li, J.; Luo, G.; Hou, Y.M.; Liu, J.; Shen, J. Incorporation of tellurocysteine into glutathione transferase generates high glutathione peroxidase efficiency. Angew. Chem. Int. Ed. 2009, 48, 2020-2023. [CrossRef] [PubMed]

134. Kirsch, G.; Goodman, M.M.; Knapp, F.F. Organotellurium compounds of biological interest-unique properties of the Nchlorosuccinimide oxidation product of 9-telluraheptadecanoic acid. Organometallics 1983, 2, 357-363. [CrossRef]

135. Jacob, C.; Arteel, G.E.; Kanda, T.; Engman, L.; Sies, H. Water-soluble organotellurium compounds: Catalytic protection against peroxynitrite and release of zinc from metallothionein. Chem. Res. Toxicol. 2000, 13, 3-9. [CrossRef]

136. Schewe, T. Molecular actions of Ebselen-an antiinflammatory antioxidant. Gen. Pharmacol. 1995, 26, 1153-1169. [CrossRef]

137. Anand, K.; Ziebuhr, J.; Wadhwani, P.; Mesters, J.R.; Hilgenfeld, R. Coronavirus main proteinase (3CLpro) structure: Basis for design of anti-SARS drugs. Science 2003, 300, 1763-1767. [CrossRef] [PubMed]

138. Briviba, K.; Tamler, R.; Klotz, L.-O.; Engman, L.; Cotgreave, I.A.; Sies, H. Protection by organotellurium compounds against peroxynitrite-mediated oxidation and nitration reactions. Biochem. Pharmacol. 1998, 55, 817-823. [CrossRef]

139. Malik, A.; Grohmann, E.; Alves, M. Management of Microbial Resources in the Environment, 1st ed.; Springer: Amsterdam, The Netherlands, 2013.

140. Patel, K.; Amaresan, N. Antimicrobial compounds from extreme environment rhizosphere organisms for plant growth. Int. J. Curr. Microbiol. Appl. Sci. 2014, 3, 651-664.

141. Yong, Y.C.; Zhong, J.J. Recent advances in biodegradation in China: New microorganisms and pathways, biodegradation engineering, and bioenergy from pollutant biodegradation. Process Biochem. 2010, 45, 1937-1943. [CrossRef] 